\title{
Mycorrhizal Inoculation Alleviates Water Deficit Impact on Field-Grown Processing Tomato
}

\author{
Jawdat Bakr ${ }^{1,2 *}$, Zoltán Pék ${ }^{2}$, Lajos Helyes ${ }^{2}$, Katalin Posta ${ }^{3}$ \\ ${ }^{1}$ Department of Ornamental Plants, Bakrajo Technical Institute, Sulaimani Polytechnic University, \\ Sulaymaniyah, Kurdistan Region, Iraq \\ ${ }^{2}$ Institute of Horticulture, Szent István University, Gödöllö, Hungary \\ ${ }^{3}$ Institute of Genetics, Microbiology and Biotechnology, , Szent István University, Gödöllő, Hungary
}

Received: 25 April 2017

Accepted: 14 October 2017

\begin{abstract}
In a field experiment, processing tomato plants inoculated with arbuscular mycorrhizae (AM) and non-inoculated (Control) were supplied with three levels of watering. The AM inoculation significantly increased tomato root colonization regardless of the water supply levels. Under water deficit conditions, AM inoculation significantly increased the biomass production (from 1,189 to 2,062 $\mathrm{g} \mathrm{plant}^{-1}$ ). AM inoculation increased the phosphorus uptake in water deficit supply (from 0.5 to $1.3 \mathrm{~g} \mathrm{plant}^{-1}$ ) and in optimum water supply (from 0.3 to $0.6 \mathrm{~g} \mathrm{plant}^{-1}$ ). Photosynthesis was not affected by irrigation, but mycorrhizal inoculation enhanced the efficiency of photosystem II at all water levels. Inoculated plants accumulated less proline, potassium, and magnesium in shoots in response to water stress. Less organic and inorganic solutes in shoots of inoculated plants were accompanied by higher water use efficiency, better stomatal conductance, and higher leaf water potential. In conclusion, AM inoculation enabled host plants to alleviate moderate water stress, modulating the physiological status of the plants for better water exploitation.
\end{abstract}

Keywords: Arbuscular mycorrhizae, phosphorus, proline, shoot inorganic solutes, water use efficiency

\section{Introduction}

Processing tomato production accounts for $41,384,000$ metric tons worldwide [1], making processing tomato one of the most important vegetable crops. Its high water demand and low availability of freshwater in irrigated field cropping systems, due to the climate change [2,3], restricts production globally. Therefore, strategies to enhance water use efficiency are required [4].

*e-mail: jawdat.bakr@gmail.com
Arbuscular mycorrhizal fungi (AMF) establish mutualistic symbioses with most land plants [5], and enhance host plant capability to overcome many abiotic and biotic stresses including water deficiency by improving water and nutrient uptake $[5,6]$ and increasing photosynthesis efficiency [6]. In exchange, host plants guarantee photosynthates and an ecological niche to its symbiotic partner [5,6]. In addition to the association with the host plant roots, AMF interacts with several microorganisms in the rhizosphere, expanding the range of beneficial processes and enhancing plant growth under stress conditions [7]. Mycorrhizae hyphal direct and indirect contribution to total root water uptake is estimated to be about $20 \%$ in separated plant-hyphal 
chambers [8], and it is considered the main mechanism for alleviating water deficit stress in host plants. AMF hyphae are two-fold thinner than the thinnest plant roots, and they have the ability to adjust the diameter depending on soil pore size [9], making AMF more suitable to access nutrients in dry and compact soils [10].

Plants can also regulate their stomatal conductance to avoid water deficit stress, a strategy that can be enhanced by association with AMF [11]. Mycorrhizal plants show greater stomatal conductance in all soil moisture conditions, but the effect of mycorrhizal association is more pronounced in moderate drought [11]. In response to drought stress, plants accumulate low-weight solutes to enhance their drought tolerance by lowering the osmotic potential. Both inorganic $\left(\mathrm{K}^{+}\right.$, $\mathrm{Ca}^{2+}$, and $\mathrm{Mg}^{2+}$ ) and organic (proline) solutes act as osmoprotectans, facilitating water uptake [12]. Tomato plants under drought stress accumulate more proline, enhancing their capability to survive and recover under short periods of drought stress [13], but the effect of AMF on proline change in plant tissues is not well understood [14].

Most studies addressing physiological aspects of mycorrhizal plants were pot-based under standardized environmental conditions [11], where plant rhizosphere was space-limited and the real AMF contribution to water and nutrients uptake was difficult to evaluate. On the other hand, field experiments, even if many variables cannot be controlled [15], offer the possibility of testing the impact of AM inoculation on drought stress tolerance in the presence of autochthonous AMF communities. Native AMF communities, although they can provide a certain protection against water deficiency stress [16,17], might invalidate the effects of AMF inoculation because of antagonistic interactions [15].

The aim of this work was to evaluate the field effectiveness of Symbivit (a commercial mixture of
AMF strains) inoculation on processing tomato (Uno Rosso F1) grown under different water supply regimes. Biomass production, water relations, photochemical efficiency, chlorophyll content, concentration of shoot organic and inorganic solutes, and phosphorus uptake were determined in response to AMF inoculation.

\section{Material and Methods}

\section{Experimental Farm}

The experiment was carried out in 2015 at the experimental farm of the Institute of Horticulture, Szent István University, Gödöllö, Hungary (47.593609N, 19.354630E). The farm had brown forest soil, sandy loam in texture with the following characteristics: $69 \%$ sand, $22 \%$ silt, and $9 \%$ clay, $1.57 \mathrm{~g} \mathrm{~cm}^{-3}$ bulk density, $19 \%$ field capacity, neutral in $\mathrm{pH}$, free from salinity $\left(0.16 \mathrm{dS} \mathrm{m}^{-1}\right)$, low in organic carbon, $\mathrm{NO}_{3}-\mathrm{N}$ $\left(5 \mathrm{mg} \mathrm{kg}^{-1}\right), \mathrm{P}_{2} \mathrm{O}_{2}\left(15 \mathrm{mg} \mathrm{kg}^{-1}\right), \mathrm{K}_{2} \mathrm{O}\left(35 \mathrm{mg} \mathrm{kg}^{-1}\right)$; the water table was below $5 \mathrm{~m}$ (with no influence on water turnover). A two-way factorial experimental design was used, with two levels of mycorrhizal inoculation and three levels of water supply. The field was divided into three blocks corresponding to the three levels of irrigation (Fig. 1). Each block was divided into four subplots (corresponding to four repetitions) per treatment. Seedlings were arranged in double (twin) rows $(20 \mathrm{~m}$ long) with $1.2 \mathrm{~m}$ and $0.4 \mathrm{~m}$ inter-row distance and $0.2 \mathrm{~m}$ between plants.

\section{AM Inoculation}

On 13 April seeds of processing tomato 'UNO ROSSO F1' (United Genetics Seeds Co. CA, USA) were sown in a greenhouse using horticulture

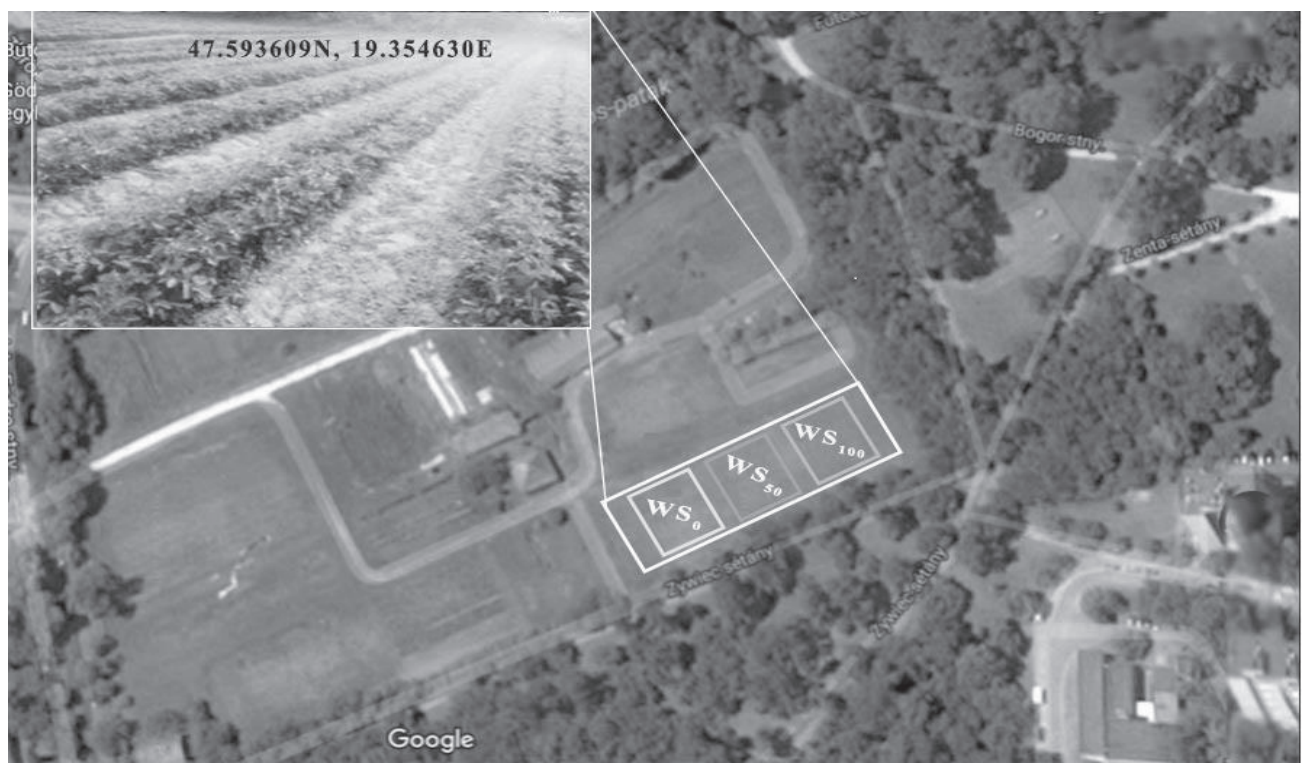

Fig. 1. Experimental farm location and design scheme. 
substrate Klasmann TS3. In the inoculation treatments (AM) a liter of the substrate received $25 \mathrm{~g}$ of the commercial product Symbivit (Funneliformis mosseae, Funneliformis geosporum, Claroideoglomus etunicatum, Claroideoglomus claroideum, Glomus microaggregatum, and Rhizophagus irregularis; names of species updated according to Schüßler and Walker [18]) produced by Symbiom Ltd. (Czech Republic, symbiom.cz). In the control treatments (Control) the substrate did not receive any type of inoculation. After 4 weeks of growth (11 May) Control and AM seedlings were transplanted to a field. AM seedlings received further inoculation corresponding to $20 \mathrm{~g}$ of Symbivit into the planting hole.

\section{Irrigation}

The daily amount of optimal irrigation was calculated using potential evapotranspiration [19] based on data from the Hungarian Meteorological Service (met.hu/en/idojaras). A drip irrigation system was used to implement three watering regimes: optimum water supply $\left(\mathrm{WS}_{100}\right)$, water deficit supply $\left(\mathrm{WS}_{50}\right)$ corresponding to $50 \%$ of the calculated irrigation demand, and no-irrigation $\left(\mathrm{WS}_{0}\right)$ treatment. A digital soil moisture meter PT1 (Kapacitív Kkt. Budapest, Hungary) was used to estimate volumetric soil water content (VWC), and records were taken at six different soil depths $(5,10,15,20,25$, and $30 \mathrm{~cm})$ just before watering. Throughout the growing season plant nutrition requirement and plant protection were regulated after Pék et al. [19].

\section{Root Colonization Assessment}

Samples were collected at harvest. Five plants per repetition (subplot) were randomly chosen and dug out (with $25 \times 25 \times 25 \mathrm{~cm}$ soil core). Five $1 \mathrm{~cm}$-long root segments per plant were stained with Trypan Blue [20]. Stereomicroscope at $\times 100$ magnification was used to check the internal fungal structures (hyphae, arbuscules). Root colonization was calculated using the gridline intersect method [21].

\section{Soil Microbial Activity}

Fluorescein diacetate (FDA) hydrolysis was used for measuring total microbial activity in a range of environmental samples, including soil [22]; therefore, the activity of fluorescein diacetate hydrolase (FDAH) was assessed as described by Adam and Duncan [23].

\section{Plant Water Status}

Water use efficiency (WUE) was calculated from the total fresh biomass (WUE $=\mathrm{kg}$ biomass per hectare/ water supply $\mathrm{m}^{-3}$ per hectare). Mycorrhizal contribution (MC \%) was estimated [24] as ([MC \% = total biomass (AM) - total biomass (Control)/ Total Biomass (AM)]).
To measure leaf water potential $\left(\psi_{\mathrm{L}}\right)$, newly mature leaves from each plant (four repetitions per treatment) were cut at midday for three consecutive weeks using a pressure bomb (PMS Instruments Co., Corvallis, OR, USA).

\section{Relative Chlorophyll Index}

Nitrogen content of the plants was measured by leaf SPAD values [25]. As a non-destructive tool, a SPAD-502 chlorophyll meter (Konica Minolta Hungary Business Solutions Ltd., Budapest, Hungary) was used to measure relative chlorophyll index as soil plant analysis development (SPAD) at the fruit setting stage. Three readings were recorded from each replication.

\section{Photosynthetic Efficiency}

Chlorophyll fluorescence was measured by a PAM 2500 portable fluorimeter (Walz-Mess und Regeltechnik, Germany) on four plants tagged for each replication. For photochemical analysis a fully developed top leaf was subjected to 35-min dark adaptation by leaf clips. PamWin 3.0 software was used to calculate the photochemical quantum yield of PSII from $\mathrm{Fv} / \mathrm{Fm}$ ratio using the kinetics method [26].

\section{Canopy Temperature}

A noncontact infrared temperature sensor (Raytek Raynger MX4, Santa Cruz, CA, USA) was used for canopy temperature measurement [27].

\section{Proline Estimation}

Proline is the only amino acid with a secondary amine, and its concentration was determined from 0.5 $\mathrm{g}$ fresh leaves based on the acid-ninhydrin method [28] modified [29], leaf crude was extracted by $3 \%$ sulfosalicylic acid and centrifuged at 3,000 rpm for 10 minutes. Two $\mathrm{ml}$ acid-ninhydrin, $2 \mathrm{ml}$ ortho-phosphoric acid (6M), and $2 \mathrm{ml}$ glacial acetic acid were added to the supernatant, followed by one-hour incubation at $100^{\circ} \mathrm{C}$. After cooling down the tubes at room temperature, the absorbance of the extracts was read at $520 \mathrm{~nm}$ using a spectrophotometer (Hitachi U-2900, Tokyo, Japan), and concentrations were calculated according to the calibration curve for proline standards.

\section{Shoot Element Concentrations}

At fruit-setting stage, eight weeks after transplantation, leaflets next to the most recent fruiting cluster from four plants of each replication were taken and dried at $65^{\circ} \mathrm{C}$ for 48 hours. Dried shoots were ground with mortar and pestle. $250 \mathrm{mg}$ of milled leaves were digested in a CEM MARS 5 (Magne-Chem Ltd., Budapest, Hungary) device using the microwave pressure digestion method for elemental analysis. 
An ICP-OES spectrometer (HORIBA Jobin Yvon ACTIVA-M, Edison, NJ, USA) was used to quantify shoot element concentrations.

\section{Analyzing Variances}

Statistical analyses were performed using IBM SPSS Statistics for Windows, version 22.0 (IBM Hungary). Means of four replications were separated by least significant difference (LSD, $\mathrm{P} \leq 0.05$ ). Analysis of variance was done by two-way ANOVA, considering mycorrhizae inoculation and water supply intensity as fixed factors to separate the mycorrhizal effect, water supply effect, and their interaction. In the case of significant interaction between AM and WS, Tukey's HSD test was performed to determine significant differences among the treatments. Before data analysis, percentage values for root colonization and mycorrhizal contribution were arc-sine [squareroot $(\mathrm{X})$ ] transformed. Pearson correlation coefficient is used to assess the direction and the strength of the linear relationship between proline content and leaf water potential variables.

\section{Results and Discussion}

\section{Precipitation, Irrigation, and Soil Water Content}

During the growing season the experimental farm received $183.6 \mathrm{~mm}$ of rain. Overall, $\mathrm{WS}_{100}$ and $\mathrm{WS}_{50}$ blocks have received, respectively, $426.3 \mathrm{~mm}$ and $306.3 \mathrm{~mm}$ (considering drip irrigation and precipitation). Soil water content ranged $0.14-0.17,0.11-0.14$, and $0.07-0.10$, corresponding to $73-89 \%, 58-73 \%$, and $37-52 \%$ of field capacity in $\mathrm{WS}_{100}, \mathrm{WS}_{50}$, and $\mathrm{WS}_{0}$ blocks, respectively. The favorable distribution of the rain events during the first two months, the last three weeks of no rain (Fig. 2), and the low water-holding capacity of the experimental soil allowed for proper water stress induction to $\mathrm{WS}_{0}-$ and $\mathrm{WS}_{50}$-treatments. Based on the midday leaf water potential, control plants faced severe water stress $\left(\psi_{\mathrm{L}}\right.$ decreased by $\left.70 \%\right)$ in $\mathrm{WS}_{0}$, and moderate water stress $\left(\psi_{\mathrm{L}}\right.$ decreased by $\left.16 \%\right)$ in $\mathrm{WS}_{50}$ compared to $\mathrm{WS}_{100}$.

\section{Root Colonization}

Despite the presence of autochthonous AMF communities, the use of the commercial inoculum increased significantly the colonization rate in AM treatments, highlighting a good adaptation ability of the AMF strains introduced in the field. Mycorrhizal inoculation increased the colonization rate significantly, reaching 78,68 , and $79 \%$ in $\mathrm{WS}_{0}, \mathrm{WS}_{50}$, and $\mathrm{WS}_{100}$ plant roots, respectively (Table 1). No effects of water supply on mycorrhizal colonization were detected. In concurrence with the increased root colonization, mycorrhizal inoculation improved growth, water use efficiency, stomatal conductance, photosynthetic efficiency (Table 2), and leaf water potential (Fig. 4a) in AM plants. This can be explained by the efficiency of exogenous mycorrhizae inoculated in enhancing root water uptake, since different fungal species can promote different ecological services [30]. Symanczik et al. [31] observed that under dry conditions the introduction of Rhizophagus irregularis, an AMF species widely used in commercial inocula, reduced the total abundance of all native AMF assemblages in roots. In the present work, in the absence of molecular analysis, it was not possible to determine if the positive effects of the inoculation were due to synergestic or antagonistic interactions between native AMF and commercial AMF strains. Mycorrhizal contribution (MC \%) to biomass production achieved the highest level of $44 \%$ in $\mathrm{WS}_{50}$, remarkably different compared to $3 \%$ and $7 \%$ measured in $\mathrm{WS}_{0}$ and $\mathrm{WS}_{100}$ regimes, respectively, suggesting

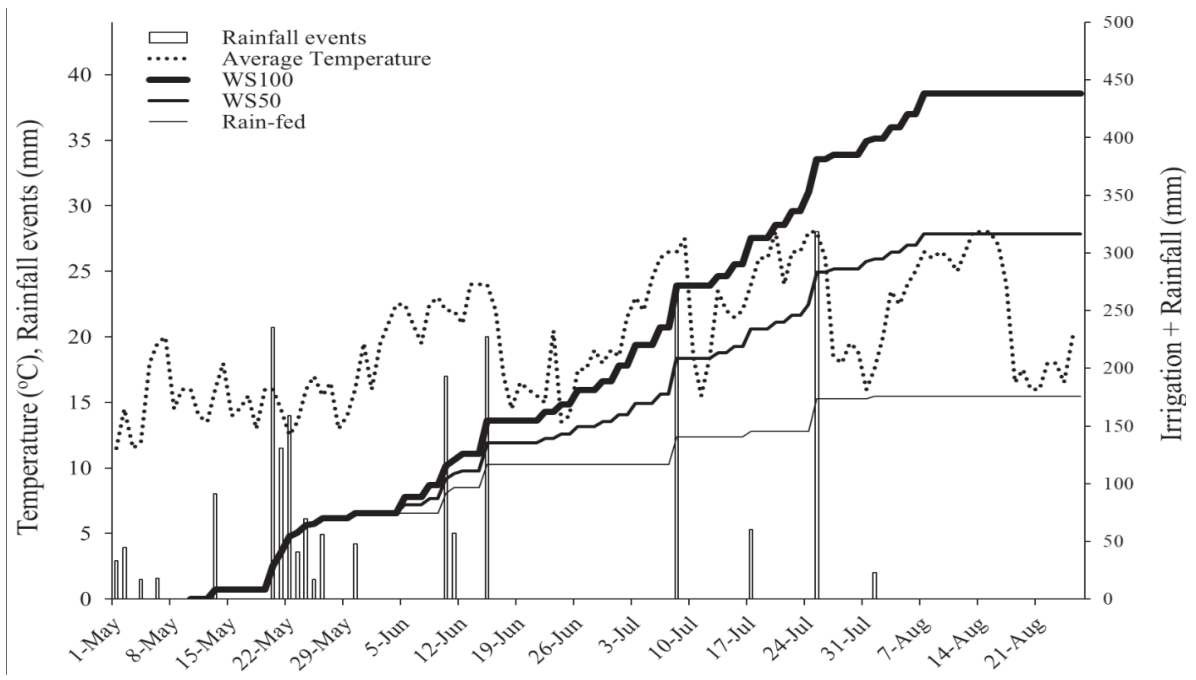

Fig. 2. Average daily temperature, precipitation, and accumulated irrigation amounts in 2015. 
Table 1. Root colonization, fluorescein diacetate (FDA), soil plant analysis development (SPAD), and mycorrhizal contribution (MC \%) of non-inoculated (control), and inoculated (AM) plants under different water supplies.

\begin{tabular}{|c|c|c|c|c|c|}
\hline Water Supply & Treatment & Root Colonization (\%) & FDA & SPAD & $\mathrm{MC}(\%)$ \\
\hline \multirow[b]{2}{*}{$\mathrm{WS}_{0}$} & Control & $57^{\mathrm{Aa}} \pm 7$ & $0.71^{\mathrm{Aa}} \pm 0.07$ & $47.0^{\mathrm{Aa}} \pm 0.5$ & \\
\hline & $\mathrm{AM}$ & $78^{\mathrm{Ba}} \pm 9$ & $0.85^{\mathrm{Bb}} \pm 0.02$ & $48.6^{\mathrm{Aa}} \pm 2.6$ & $2.87^{\mathrm{a}}$ \\
\hline \multirow[b]{2}{*}{$\mathrm{WS}_{50}$} & Control & $52^{\mathrm{Aa}} \pm 7$ & $0.62^{\mathrm{Aa}} \pm 0.12$ & $46.4^{\mathrm{Aa}} \pm 0.7$ & \\
\hline & $\mathrm{AM}$ & $68^{\mathrm{Ba}} \pm 11$ & $0.68^{\mathrm{Aa}} \pm 0.18$ & $48.5^{\mathrm{Ba}} \pm 1.5$ & $43.74^{c}$ \\
\hline \multirow{2}{*}{$\mathrm{WS}_{100}$} & Control & $58^{\mathrm{Aa}} \pm 7$ & $0.64^{\mathrm{Aa}} \pm 0.03$ & $47.0^{\mathrm{Aa}} \pm 1.7$ & \\
\hline & $\mathrm{AM}$ & $79^{\mathrm{Ba}} \pm 8$ & $0.64^{\mathrm{Aa}} \pm 0.10$ & $47.7^{\mathrm{Aa}} \pm 1.9$ & $7.33^{\mathrm{b}}$ \\
\hline \multicolumn{6}{|c|}{ Significant of Source of variation $\quad(\mathrm{ns}=$ not significant, $* \mathrm{P} \leq 0.05, \quad * * \mathrm{P} \leq 0.01, \quad * * * \mathrm{P} \leq 0.001)$} \\
\hline \multicolumn{2}{|c|}{ Mycorrhizae inoculation (AM) } & $* * *$ & $* *$ & * & \\
\hline \multicolumn{2}{|c|}{ Water Supply (WS) } & ns & $*$ & ns & \\
\hline \multicolumn{2}{|c|}{$\mathrm{AM} * \mathrm{WS}$} & ns & ns & ns & \\
\hline
\end{tabular}

Means within a column not followed by same letters are significantly different at $(\mathrm{P}<0.05)$ as determined by Tukey's HSD test $(\mathrm{n}=4)$; capital letters represent mycorrhizal effect, small letters represent water supply effect

better performance of the inoculated AMF under moderate water stress.

\section{Microbial Activity}

Fluorescein diacetate (FDA) hydrolysis indicated higher microbial activity in the rhizosphere of AM plants in $\mathrm{WS}_{50}$ and $\mathrm{WS}_{0}$ blocks (Table 1); this may be related to the positive influence of arbuscular mycorrhizal mycelial exudates on soil bacterial growth, and the synergestic interactions between AMF and rhizosphere microbiota [32].

\section{Photosynthetic Efficiency and Relative} Chlorophyll Index

Comparing the different water supply regimes, water deficit stress decreased the photosynthetic efficiency of photosystem II only in $\mathrm{WS}_{0}$. Mycorrhizal inoculation increased substantially photosynthetic efficiency at all water supply levels (Table 2), leading to plant growth improvement [33], and indicating less damage to the photosynthetic apparatus in inoculated plants under water deficiency conditions [34]. According to other authors $[35,36]$ enhanced photosynthesis performance

Table 2. Total biomass, water use efficiency (WUE), stomatal conductance $\left(\mathrm{g}_{\mathrm{s}}\right)$, photosynthetic efficiency (Fv/Fm), and canopy temperature (C.t.) of non-inoculated (control), and inoculated (AM) plants under different water supplies.

\begin{tabular}{|c|c|c|c|c|c|c|}
\hline Water Supply & Treatment & $\begin{array}{l}\text { Biomass } \\
\text { (g) plant }{ }^{-1}\end{array}$ & $\begin{array}{l}\text { WUE } \\
\left(\mathrm{kg} / \mathrm{m}^{3}\right)\end{array}$ &  & $\mathrm{Fv} / \mathrm{Fm}$ & C.t. $\left({ }^{\circ} \mathrm{C}\right)$ \\
\hline \multirow{2}{*}{$\mathrm{WS}_{0}$} & Control & $536^{\mathrm{Aa}} \pm 72$ & $18.0^{\mathrm{Aa}} \pm 2$ & $9.92^{\mathrm{Aa}}$ & $0.66^{\mathrm{Aa}} \pm .05$ & $34.1^{\mathrm{Ac}}$ \\
\hline & $\mathrm{AM}$ & $553^{\mathrm{Aa}} \pm 47$ & $18.6^{\mathrm{Aa}} \pm 1$ & $9.75^{\mathrm{Aa}}$ & $0.74^{\mathrm{Ba}} \pm .03$ & $34.1^{\mathrm{Ac}}$ \\
\hline \multirow{2}{*}{$\mathrm{WS}_{50}$} & Control & $1,189^{\mathrm{Ab}} \pm 46$ & $24.3^{\mathrm{Ab}} \pm 1$ & $18.22^{\mathrm{Ab}}$ & $0.75^{\mathrm{Ab}} \pm .02$ & $30.6^{\mathrm{Ab}}$ \\
\hline & $\mathrm{AM}$ & $2,062^{\mathrm{Bc}} \pm 50$ & $42.1^{\mathrm{Bc}} \pm 1$ & $24.88^{\mathrm{Bb}}$ & $0.78^{\mathrm{Bb}} \pm .03$ & $29.0^{\mathrm{Bb}}$ \\
\hline \multirow{2}{*}{$W_{100}$} & Control & $1,481^{\mathrm{Ac}_{ \pm}}+38$ & $21.7^{\mathrm{Ac}} \pm 1$ & $29.52^{\mathrm{Ac}}$ & $0.75^{\mathrm{Ab}} \pm .04$ & $28.2^{\mathrm{Aa}}$ \\
\hline & $\mathrm{AM}$ & $1,601^{\mathrm{Bb}} \pm 84$ & $23.5^{\mathrm{Bb}} \pm 1$ & $29.96^{\mathrm{Ac}}$ & $0.77^{\mathrm{Bb}} \pm .01$ & $27.8^{\mathrm{Aa}}$ \\
\hline \multicolumn{7}{|c|}{ Significant of Source of variation $\quad(\mathrm{ns}=$ not significant, $\quad * \mathrm{P} \leq 0.05, \quad * * \mathrm{P} \leq 0.01, \quad * * * \mathrm{P} \leq 0.001)$} \\
\hline \multicolumn{2}{|c|}{ Mycorrhizae inoculation (AM) } & $* * *$ & $* * *$ & $* * *$ & $* * *$ & *** \\
\hline \multicolumn{2}{|c|}{ Water Supply (WS) } & $* * *$ & $* * *$ & $* * *$ & $* * *$ & $* * *$ \\
\hline \multicolumn{2}{|c|}{$\mathrm{AM} * \mathrm{WS}$} & $* * *$ & $* * *$ & $* * *$ & ns & $* * *$ \\
\hline
\end{tabular}

Means within a column not followed by same letters are significantly different at $(\mathrm{P}<0.05)$ as determined by Tukey's HSD test $(\mathrm{n}=4)$; capital letters represent mycorrhizal effect small letters represent water supply effect 
under drought stress conditions would be related to a higher chlorophyll content in inoculated plants.

Mycorrhizal inoculation enhanced relative chlorophyll index (SPAD unit) only in $\mathrm{WS}_{50}$, with a remarkable change neither in $\mathrm{WS}_{0}$ nor in $\mathrm{WS}_{100}$ (Table 1). In the control treatments a water shortage did not change leaf SPAD values of tomato, while other authors reported contrasting results [35-37] in response to drought stress.

\section{Shoot Phosphorus Concentration and Phosphorus Uptake}

The soil of the experimental farm was considered low in plant-available $\mathrm{P}\left(\mathrm{P}_{2} \mathrm{O}_{2}=15 \mathrm{mg} \mathrm{kg}^{-1}\right)$. Shoot phosphorus concentration was affected by water supply (Fig. 3a). In the Control treatment the highest value was recorded in the unirrigated block. To give a thorough explanation of this result, it is useful to recall the outcome of previous research in the same experimental field, focused on the yield of processing tomato crop [38]. In the control plants under unirrigated water regime, the highest $\mathrm{P}$ concentration in the shoots would be explained by a lesser translocation of nutrients during fruit setting (because of the smaller amount of fruits compared to the irrigatied regimes). P uptake, calculated as "shoot $\mathrm{P}$ concentration $\mathrm{x}$ shoot mass," would be consequently higher in $\mathrm{WS}_{0}$ where, besides the highest $\mathrm{P}$ concentration, the lack of fruits was compensated for by more shoots. In agreement with the explanation, $\mathrm{P}$ uptake per plant decreased to the half in $\mathrm{WS}_{50}\left(0.05 \mathrm{~g} \mathrm{plant}^{-1}\right)$, and to one third $\left(0.03 \mathrm{~g} \mathrm{plant}^{-1}\right)$ in $\mathrm{WS}_{100}$ (Fig. 3b). In mycorrhizal plants a similar trend in the shoot $\mathrm{P}$ concentration was observed. Under water deficit conditions in AM plants the concentration was slightly but significantly higher than of control plants. No influence of AM inoculation on leaf-P concentration under optimum water conditions was recorded, confirming the findings of Conversa et al. [39] in a 2-year field experiment on processing tomato. Considering the $\mathrm{P}$ uptake, the values of AM plants in $\mathrm{WS}_{50}$ were remarkably higher compared to the control plants, especially because of shoot production almost 2.5-fold higher. Accordingly to this result, the moderate a)


Fig. 3. Shoot phosphorus concentration a) and phosphorus uptake b) of non-inoculated (control), and inoculated (AM) plants under different water supply intensities; vertical bars represent standard deviation, capital letters represent mycorrhizal effect, and small letters represent water supply effect. a) Water Supply Intensities

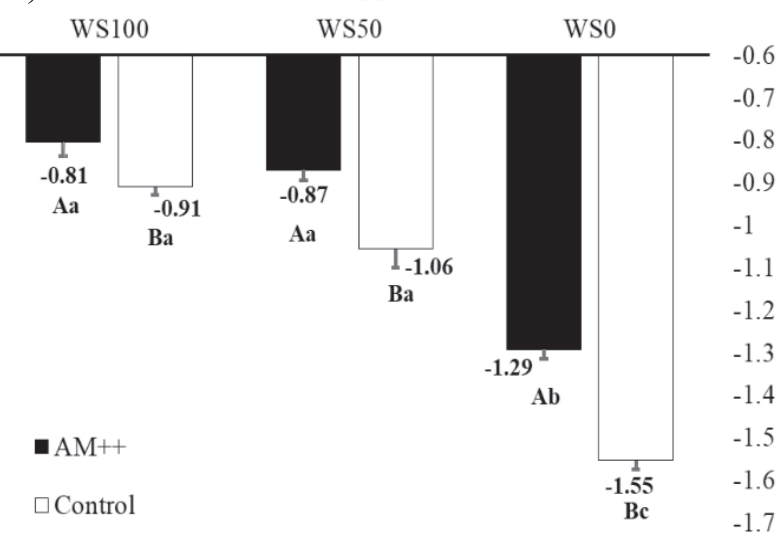

b)
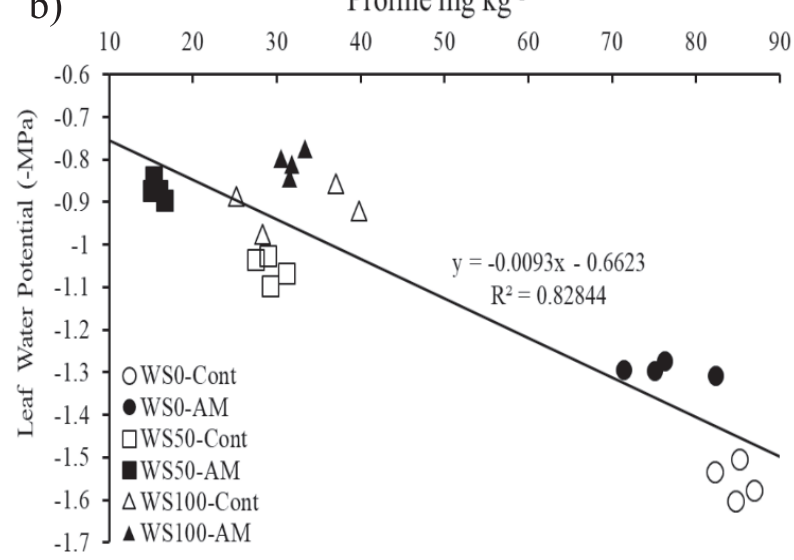

Fig. 4. Leaf water potential a) leaf proline concentration, and leaf water potential relationship b) of non-inoculated (control), and inoculated (AM) plants under different water supply intensities; vertical bars represent standard deviation, capital letters represent mycorrhizal effect, small letters represent water supply effect. 
water deficit appeared to be the best condition for the AMF inocula to promote nutrient (particularly P) uptake in the host plants.

\section{Total Biomass and Water Use Efficiency}

Unirrigated water regime shortened the growth period by 2 weeks, therefore total biomass and fruits of $\mathrm{WS}_{0}$ tomato plant stands were harvested first, on 11 August, followed by $\mathrm{WS}_{50}$ and $\mathrm{WS}_{100}$ - both on 25 August. In the Control plants the reduction of water supply had a negative impact on the above-ground total fresh biomass (fruits, stem, and leaves) with a decrease of 25 and $175 \%$ in both $\mathrm{WS}_{50}$ and $\mathrm{WS}_{0}$, respectively. On the contrary, AM plants increased the total fresh biomass by $73 \%$ in $\mathrm{WS}_{50}$, while a slight increase of 3 and $8 \%$ was observed in $\mathrm{WS}_{0}$ and $\mathrm{WS}_{100}$ treatments (Table 2). The remarkable enhancement in growth performance by AM inoculation, when plants were moderately stressed, can be explained by the co-occurring highest $\mathrm{P}$ uptake [5] and the best photosynthesis performances [40] described in the previous sections.

Despite the increase of total fresh biomass, along with water supply intensification, water use efficiency (calculated from the total biomass) did not improve when water supply increased to fulfill plants water requirement. WUE was slightly enhanced by AM inoculation in $\mathrm{WS}_{100}$, with no change in $\mathrm{WS}_{\mathbf{0}}$. AM plants recorded the highest value of WUE $(42.1 \mathrm{~kg}$ aboveground biomass production per cubic meter water consumed) in $\mathrm{WS}_{50}$ (Table 2), in accordance with previous data on processing tomato under field conditions [41,42]. Bárzana et al. [34] observed that the enhancement of plants root hydraulic properties by AM, in addition to higher flexibility of mycorrhizal roots to switch between water-transport pathways in response to water deficit stress, improved mycorrhizal roots ability to uptake water from the soil, leading to more efficient use of water.

\section{Leaf Water Potential, Stomatal Conductance, and Canopy Temperature}

Leaf water potential is the most important index of plant water status. Reducing the water supply, in control plants the leaf water potential $\left(\psi_{\mathrm{L}}\right)$ decreased from -0.91 $\mathrm{MPa}$ in $\mathrm{WS}_{100}$ to $-1.06 \mathrm{MPa}$ in $\mathrm{WS}_{50}$, and $-1.55 \mathrm{MPa}$ in $\mathrm{WS}_{0}$ (Fig. 4a). AM inoculation remarkably increased the $\psi_{\mathrm{L}}$ in plant leaves by 20,22 , and $12 \%$ in $\mathrm{WS}_{0}, \mathrm{WS}_{50}$, and $\mathrm{WS}_{100}$, respectively. Our results confirmed the findings of recent studies on maize and tomatoes [34], and snapdragon [43], illustrating higher leaf water potential in host plants colonized by arbuscular mycorrhizal fungi.

Independent of inoculation, stomatal conductance decreased in concurrence with the reduction of water supply (Table 2). Plants lost two thirds of their stomatal conductance in $\mathrm{WS}_{0}$ compared to $\mathrm{WS}_{100}$. A meaningful increase (from 18.22 to $24.88 \mathrm{mmol} \mathrm{m}^{-2} \mathrm{~s}^{-1}$ ) was observed in AM plants compared to Control plants in $\mathrm{WS}_{50}$. A meta-analysis [11] showed AM plants to have higher stomatal conductance than non-mycorrhizal plants under all soil moisture conditions, with greater inoculation effect under moderate drought stress.

A reverse trend was observed in canopy temperature with a gradual decrease in Control plants along with the increase of irrigation amount - from $34.1^{\circ} \mathrm{C}$ in $\mathrm{WS}_{0}$ to $30.6^{\circ} \mathrm{C}$ in $\mathrm{WS}_{50}$ and $28^{\circ} \mathrm{C}$ in $\mathrm{WS}_{100^{\circ}}$. Mycorrhizal inoculation decreased canopy temperature more effectively (from 30.6 to $29.0^{\circ} \mathrm{C}$ ) in $\mathrm{WS}_{50}$ (Table 2). This result is in agreement with the best water status detected in $\mathrm{AM}$ plants in $\mathrm{WS}_{50}$, being the canopy temperature inversely proportional to stomatal conductance [44].

Table 3. Organic and inorganic solute contents $\left(\mathrm{mg} \mathrm{kg}^{-1}\right)$ of non-inoculated (control), and inoculated (AM) plants under different water supplies. Fresh weight (FW), dry weight (DW).

\begin{tabular}{|c|c|c|c|c|c|}
\hline Water Supply & Treatment & Proline $(\mathrm{FW})$ & $\mathrm{K}^{+}(\mathrm{DW})$ & $\mathrm{Ca}^{2+}(\mathrm{DW})$ & $\mathrm{Mg}^{2+}(\mathrm{DW})$ \\
\hline \multirow{2}{*}{$\mathrm{WS}_{0}$} & Control & $84.8^{\mathrm{Bb}}$ & $35,852^{\mathrm{Bb}}$ & $34,608^{\mathrm{Aa}}$ & $6,153^{\mathrm{Aa}}$ \\
\hline & $\mathrm{AM}$ & $76.2^{\mathrm{Ac}}$ & $28,215^{\mathrm{Ab}}$ & $38,598^{\mathrm{Aa}}$ & $5,810^{\mathrm{Aa}}$ \\
\hline \multirow{2}{*}{$\mathrm{WS}_{50}$} & Control & $29.2^{\mathrm{Ba}}$ & $32,319^{\mathrm{Ab}}$ & $41,275^{\mathrm{Aa}}$ & $6,338^{\mathrm{Ba}}$ \\
\hline & $\mathrm{AM}$ & $15.7^{\mathrm{Aa}}$ & $30,344^{\mathrm{Ab}}$ & $42,582^{\mathrm{Aa}}$ & $5,199^{\mathrm{Aa}}$ \\
\hline \multirow{2}{*}{$\mathrm{WS}_{100}$} & Control & $32.6^{\mathrm{Ab}}$ & $23,601^{\mathrm{Aa}}$ & $48,385^{\mathrm{Ba}}$ & $6,068^{\mathrm{Ba}}$ \\
\hline & $\mathrm{AM}$ & $31.8^{\mathrm{Ab}}$ & $20,563^{\mathrm{Aa}}$ & $36,719^{\mathrm{Aa}}$ & $5,45^{0 \mathrm{~A}} \mathrm{a}$ \\
\hline \multicolumn{6}{|c|}{ Significant of Source of variation $\quad(\mathrm{ns}=$ not significant, $\quad * \mathrm{P} \leq 0.05, \quad * * \mathrm{P} \leq 0.01, \quad * * * \mathrm{P} \leq 0.001)$} \\
\hline \multicolumn{2}{|c|}{ Mycorrhizae inoculation (AM) } & $* * *$ & * & $\mathrm{ns}$ & ns \\
\hline \multicolumn{2}{|c|}{ Water Supply (WS) } & $* * *$ & $* * *$ & ns & $\mathrm{ns}$ \\
\hline \multicolumn{2}{|c|}{$\mathrm{AM} * \mathrm{WS}$} & $* *$ & ns & $*$ & ns \\
\hline
\end{tabular}

Means within a column not followed by same letters are significantly different at $(\mathrm{P}<0.05)$ as determined by Tukey's HSD test ( $\mathrm{n}=4)$. Capital letters represent mycorrhizal effect, small letters represent water supply effect. 
Organic and Inorganic Solutes

Plants accumulate organic solutes such as proline and soluble sugars under water stress conditions in order to cope and recover from short periods of drought stress. In $\mathrm{WS}_{0}$ block proline concentrations in shoots increased by almost 2.5-fold (84.8 and $76.2 \mathrm{mg} \mathrm{kg}^{-1}$ ) compared to $\mathrm{WS}_{100}$ in both control and AM plants (32.6 and $31.8 \mathrm{mg} \mathrm{kg}^{-1}$ ). Although inoculation decreased the proline concentration in $\mathrm{WS}_{100}$, the difference was not significant. In $\mathrm{WS}_{50}$ proline decreased to the half in AM plants (15.7 $\mathrm{mg} \mathrm{kg}^{-1}$ ) compared to control (29.2 mg kg-1; Table 3). Other studies [45,46] have reported results in contrast with our findings; proline concentrations were shown to increase in leaf tissues of mycorrhizal plants, as osmoprotectant in response to water stress conditions. We propose that the AM inoculation in our study ameliorated the water status of the plants and prevented partially the induction of a proline-dependent drought tolerance mechanism. A similar explanation was given by Ruiz-Sánchez et al. [6] in a pot study, where mycorrhizal plants, being able to avoid water deficit stress more successfully, showed lower levels of osmolytes in the shoots. A further support to our hypothesis was found in the very strong negative correlation $(\mathrm{r}=0.91)$ observed between $\psi_{\mathrm{L}}$ and proline concentration in shoots (Fig. 4b). Higher leaf water potential and lower proline content in mycorrhizal plant shoots indicated that AM plants were not stressed during the water deficit period. Similar results were also observed in pot experiments with different plant species inoculated with AM fungi and undergoing drought stress: Ruiz-Sánchez et al. in rice [6], Asrar et al. in snapdragon [43], Doubková et al. in field scabious [47], and Padmavathi et al. in tomato and bell pepper [48].

Regardless of mycorrhizal inoculation, water supply reduction caused an increase in $\mathrm{K}^{+}$concentrations in plant shoots in both $\mathrm{WS}_{50}$ and $\mathrm{WS}_{0}$ regimes (Table 3). Overall, AM plants accumulated less $\mathrm{K}^{+}$in shoots compared to control plants, with a significant shift in $\mathrm{WS}_{0}$ regime (from 35,852 to $28,215 \mathrm{mg} \mathrm{kg}^{-1}$ ). Considering its role in the osmotic regulation and carbon dioxide assimilation [49], our findings implied (as for the proline) a lesser need of potassium in AM plants in response to water stress due to better water use efficiency.

Similarly, mycorrhizal inoculation decreased $\mathrm{Mg}^{+2}$ concentrations in all water regimes, reaching significant differences in $\mathrm{WS}_{\mathbf{5 0}}$ and $\mathrm{WS}_{\mathbf{1 0 0}}$ (Table 3). Water supply did not affect $\mathrm{Ca}^{+2}$ concentrations in plant shoots; unexpectedly, mycorrhizal inoculation influence was observed only in relation to a reduction of calcium concentration in $\mathrm{WS}_{100}$, where the optimum water supply conditions suggested an absence of water limitation stress. The modulation of calcium concentration by AM inoculation appeared, therefore, to be related to a physiological pathway different from drought stress tolerance.

\section{Conclusions}

Mycorrhizal inoculation improved the performances of tomato plants compared to the control treatments, particulary under moderate drought stress. In the water deficit regime, significant differences were observed in the biomass production, WUE, phosphate uptake, and several other physiological parameters, leading to a partial inhibition of the osmolytes-dependent drought tolerance mechanisms. Our results encourage the use of AM inocula as "bio-enhancers" of plant performance in industrial-scale agriculture systems, and further studies are needed to evaluate the efficiency of different formulations for AMF propagules and appropriate means for their application under different field conditions.

\section{Acknowledgements}

We would like to thank the Stipendium Hungaricum, Research Center of Excellence 1476-4/2016/FEKUT. This research was supported by the Higher Education Institutional Excellence Program awarded by the Ministry of Human Capacities within the framework of water related researches of Szent István University.

The publication was supported by the EFOP-3.6.3.VEKOP-16.-2017-00008 project. The project is cofinanced by the European Union and the European Social Fund.

\section{References}

1. World processing tomato Council. Available online: http://www.wptc.to/pdf/releases/WPTC\%20World\%20 Production\%20estimate.pdf (accessed on 22. 04. 2017).

2. TRENBERTH K.E., DAI A., VAN DER SCHRIER G., JONES P.D., BARICHIVICH J., BRIFFA K.R., SHEFFIELD J. Global warming and changes in drought. Nat. Clim. Chang. 4 (1), 17, 2014.

3. FAROOQ M., WAHID A., KOBAYASHI N., FUJITA D., BASRA S.M.A. Plant drought stress: effects, mechanisms and management. Agron Sustain. Dev. 29 (1), 185, 2009.

4. PATANÈ C., TRINGALI S., SORTINO O. Effects of deficit irrigation on biomass, yield, water productivity and fruit quality of processing tomato under semi-arid mediterranean climate conditions. Sci. Hort. 129 (4), 590, 2011.

5. SMITH S.E., READ D.J. Mycorrhizal symbiosis, $3^{\text {rd }}$ ed. Academic Press, Cambridge, UK, 2008.

6. RUIZ-SÁNCHEZ M., AROCA R., MUÑOZ Y. ARMADA E., POLÓN R., RUIZ-LOZANO J.M. The arbuscular mycorrhizal symbiosis enhances the photosynthetic efficiency and the antioxidative response of rice plants subjected to drought stress. J. Plant Physiol. 167 (11), 862, 2010.

7. AZCÓN R., BAREA J.M. Mycorrhizosphere interactions for legume improvement. In Microbes for legume improvement, ed. Khan M.S., Zaidi A., Musarrat J., Springer: Vienna, Austria, Volume 2010, 237, 2010. 
8. RUTH B., KHALVATI M., SCHMIDHALTER U. Quantification of mycorrhizal water uptake via high-resolution on-line water content sensors. Plant Soil. 342 (1-2), 459, 2011

9. SMITH S.E., FACELLI E., POPE S., SMITH F.A. Plant performance in stressful environments: interpreting new and estiablished knowledge of the roles of arbuscular mycorrhizas. Plant Soil. 326 (1-2), 3, 2010.

10. NEUMANN E., GEORGE E. Colonisation with the arbuscular mycorrhizal fungus Glomus mosseae (Nicol. $\&$ Gerd.) enhanced phosphorus uptake from dry soil in Sorghum bicolor (L.). Plant Soil. 261 (1-2), 245, 2004.

11. AUGÉ R.M., TOLER H.D., SAXTON A.M. Arbuscular mycorrhizal symbiosis alters stomatal conductance of host plants more under drought than under amply watered conditions: a meta-analysis. Mycorrhiza. 25 (1), 13, 2015.

12. GHARBI E., MARTÍNEZ J.P., BENAHMED H., HICHRI I., DOBREV P.I., MOTYKA V., QUINET Q., LUTTS S. Phytohormone profiling in relation to osmotic adjustment in $\mathrm{NaCl}$-treated plants of the halophyte tomato wild relative species Solanum chilense comparatively to the cultivated glycophyte Solanum lycopersicum. Plant Sci. 258, 77, 2017.

13. PATANÈ C., SCORDIA D., TESTA G., COSENTINO, S.L. Physiological screening for drought tolerance in Mediterranean long-storage tomato. Plant Sci. 249, 25, 2016.

14. LATEF A.A.H.A., HASHM A., RASOOL S., ABD ALLAH E.F., ALQARAWI A.A., EGAMBERDIEVĀ D., JAN S., ANJUM N.A., AHMAD P. Arbuscular Mycorrhizal Symbiosis and Abiotic Stress in Plants. J. Plant Biol. 59 (5), 407, 2016.

15. SUZUKI N., RIVERO R.M., SHULAEV V., BLUMWALD E., MITTLER R. Abiotic and biotic stress combinations. New Phytol. 203 (1), 32, 2014.

16. ORTIZ N., ARMADAA E., DUQUE E., ROLDÁNC A., AZCÓNA. R. Contribution of arbuscular mycorrhizal fungi and/or bacteria to enhancing plant drought tolerance under natural soil conditions: Effectiveness of autochthonous or allochthonous strains. J. Plant Physiol. 174, 87, 2015.

17. ARMADA E., AZCÓN R., LÓPEZ-CASTILLO O.M., CALVO-POLANCO M., RUIZ-LOZANO J.M. Autochthonous arbuscular mycorrhizal fungi and Bacillus thuringiensis from a degraded Mediterranean area can be used to improve physiological traits and performance of a plant of agronomic interest under drought conditions. Plant Physiol. Biochem. 90, 64, 2015.

18. SCHÜßLER A., WALKER C. The Glomeromycota: a species list with new families and genera. Arthur Schüßler \& Christopher Walker, Gloucester. 2010.

19. PÉK Z., SZUVANDZSIEV P., DAOOD H.G., NEMÉNYI A., HELYES L. Effect of irrigation on yield parameters and antioxidant profiles of processing cherry tomato. Open Life Sci. 9 (4), 383, 2014

20. VIERHEILIG.H., PICHÉ Y. A modified procedure for staining arbuscular mycorrhizal fungi in roots. J. Plant Nutr Soil Sci. 161 (5), 601, 1998.

21. GIOVANNETTI M., MOSSE B. An evaluation of the techniques for measuring vesicular arbuscular mycorrhizal infections in roots. New Phytol. 84 (3), 489, 1980.

22. GREENA V.S., STOTTB D.E., DIACK. M. Assay for fluorescein diacetate hydrolytic activity: Optimization for soil samples. Soil Biol. Biochem. 38 (4), 693, 2006.

23. ADAM G., DUNCAN H. Development of a sensitive and rapid method for the measurement of total microbial activity using fluorescein diacetate (FDA) in a range of soils. Soil. Biol. Biochem. 33 (7-8), 943, 2001.

24. KUMAR A., SHARMA S., MISHRA S. Influence of arbuscularmycorrhizal (AM) fungi and salinity on seedling growth, solute accumulation, and mycorrhizal dependency of Jatropha curcas L. J. Plant Growth Regul. 29 (3), 297, 2010.

25. MARTÍNEZ F., PALENCIA P., WEILAND C.M., ALONSO D., OLIVEIRA J.A. Influence of nitrification inhibitor DMPP on yield, fruit quality and SPAD values of strawberry plants. Sci. Hort. 185, 233, 2015.

26. VAN GOETHEM D., DE SMEDT S., VALCKE R., POTTERS G., SAMSON R. Seasonal, diurnal and vertical variation of chlorophyll fluorescence on Phyllostachys humilis in Ireland. Plos one. 8 (8), e72145, 2013.

27. BÖCS A., PÉK Z., HELYES L., NEMÉNYI A., KOMJÁTHY L. Effect of water supply on canopy temperature and yield of processing tomato. Cer. Res. Comm., 376, 1, 113, 2009.

28. BATES L.S., WALDREN R.P., TEARE I.D. Rapid determination of free proline for water-stress studies. Plant Soil. 39 (1), 205, 1973.

29. Claussen W. Proline as a measure of stress in tomato plants. Plant Sci. 168 (1), 241, 2005.

30. BAUM C., EL-TOHAMY W., GRUDA N. Increasing the productivity and product quality of vegetable crops using arbuscular mycorrhizal fungi. Sci. Hort. 187, 131, 2015.

31. SYMANCZIK S.,COURTY P-E., BOLLER T., WIEMKEN A., AL-YAHYA'EI M.N. Impact of water regimes on an experimental community of four desert arbuscular mycorrhizal fungal (AMF) species, as affected by the introduction of a non-native AMF species. Mycorrhiza. 25 (8), 639, 2015.

32. BAREA J.M., AZCON R., AZCON-AGUILAR C. Mycorrhizosphere interactions to improve plant fitness and soil quality. Antonie van Leeuwenhoek 81 (1-4), 343, 2002.

33. JEZDINSKY A., VOJTISKOVA J., SLEZAK K., PETRIKOVA K., POKLUDA. R. Effect of drought stress and Glomus inoculation on selected physiological processes of sweet pepper (Capsicum annuum L. cv 'Slavy'). Acta Univer. Agricul. Silvicul. Mendelianae Brunensis. 60 (3), 69, 2012

34. BÁRZANA G., AROCA R., PAZ J.A., CHAUMONT F., MARTINEZ-BALLESTA M.C. CARVAJAL M., RUIZ-LOZANO J.M. Arbuscular mycorrhizal symbiosis increases relative apoplastic water flow in roots of the host plant under both well-watered and drought stress conditions. Ann. Bot. 109 (5), 1009, 2012.

35. COYNE P.I., AIKEN R.M., MAAS S.J., LAMM F.R. Evaluating yield tracker forecasts for maize in western Kansas. Agron J. 101 (3), 671, 2009.

36. ZHANG Y., YAO Q., LI J., HU Y., CHEN J. Growth response and nutrient uptake of Eriobotrya japonica plants inoculated with three isolates of arbuscular mycorrhizal fungi under water stress condition. J. Plant Nutr. 37 (5), 690, 2014.

37. PATANÈ C., PELlEGRINO A., SAITA A. Nitrogen use efficiency of processing tomato under deficit irrigation in semi-arid climate. Acta Hort. 1150, 329, 2017.

38. BAKR J., DAOOD H.G., PÉK Z., HELYES L., POSTA K. Yield and quality of mycorrhized processing tomato under water scarcity. Appl. Ecol. Env. Res. 15 (1), 401, 2017.

39. CONVERSA G., LAZZIZERA C., BONASIA A., ELIA A. Yield and phosphorus uptake of a processing tomato crop grown at different phosphorus levels in a calcareous 
soil as affected by mycorrhizal inoculation under field conditions. Biol. Fertil. Soils 49 (6), 691, 2013.

40. BIRHANE E., STERCK F.J., FETENE M., BONGERS F., KUYPER T.W. Arbuscular mycorrhizal fungi enhance photosynthesis, water use efficiency, and growth of frankincense seedlings under pulsed water availability conditions. Oecol. $\mathbf{1 6 9}(4), 895,2012$

41. CANDIDO V., CAMPANELLI G., D'ADDABBO T., CASTRONUOVO D., PERNIOLA M., CAMELE I. Growth and yield promoting effect of artificial mycorrhization on field tomato at different irrigation regimes. Sci. Hort. 187, 35, 2015.

42. PATANÈ C., LA ROSA S., PELLEGRINO A., SORTINO O., SAITA A. Water productivity and yield response factor in two cultivars of Processing tomato as affected by deficit irrigation under semi-arid climate conditions. Acta Hort. 1038, 449, 2014

43. ASRAR A.A., ABDEL-FATTAH G.M., ELHINDI K.M. Improving growth, flower yield, and water relations of snapdragon (Antirhinum majus L.) plants grown under well-watered and water-stress conditions using arbuscular mycorrhizal fungi. Photosynthetica. 50 (2), 305, 2012.

44. YU M.H., DING G.D., GAO G.L., ZHAO Y.Y., YAN L., SAI K. Using Plant Temperature to Evaluate the Response of Stomatal Conductance to Soil Moisture Deficit. Forests. 6 (10), 3748, 2015.

45. FAN Q.J., LIU J.H. Colonization with arbuscular mycorrhizal fungus affects growth, drought tolerance and expression of stress-responsive genes in Poncirus trifoliata. Acta. Physiol. Plant. 33 (4), 1533, 2011.

46. YOOYONGWECH S., PHAUKINSANG N., CHA-UM S., SUPAIBULWATANA K. Arbuscular mycorrhiza improved growth performance in Macadamia tetraphylla L. grown under water deficit stress involves soluble sugar and proline accumulation. Plant Growth Regul. 69 (3), 285, 2013.

47. DOUBKOVÁ P., VLASÁKOVÁ E., SUDOVÁ R. Arbuscular mycorrhizal symbiosis alleviates drought stress imposed on Knautia arvensis plants in serpentine soil. Plant Soil. 370 (1-2), 149, 2013.

48. PADMAVATHI T., RASHMI D., SWETHA S. Influence of Rhizophagus spp. and Burkholderia seminalis on the Growth of Tomato (Lycopersicon esculatum) and Bell Pepper (Capsicum annuum) under Drought Stress. Commun. Soil Sci. Plant Anal. 47 (17), 1975, 2016.

49. RÖMHELD V., KIRKBY E.A. Research on potassium in agriculture: needs and prospects. Plant Soil. 335 (1-2), 155, 2010. 